\title{
Immobilization of Thrombin to Alginate Gel and In Vitro Application of Immobilized Thrombin
}

\author{
Trombinin Alginat Jeline İmmobilizasyonu ve İmmobilize \\ Trombinin In Vitro Uygulaması
}

\section{Research Article}

Alper Akkaya

Ege University, Faculty of Science, Biochemistry Department, Bornova, Izmir, Turkey.

\section{A BSTRACT}

\begin{abstract}
leeding is one of the biggest problems of humanity. Blood loss in road traffic accidents and surgical operations is an important cause of death. In this study, a product which could decrease bleeding time was developed. The production process of developed product was very simple and the product has commercialization potential. Thrombin was immobilized to calcium alginate beads via ionic interactions. In this method, negative charged carboxylate groups of calcium alginate interacted ionically with the positive charge of thrombin. Optimization studies of thrombin immobilization were performed for increasing immobilization efficiency and it was found to be $4.1 \%$ at the end of optimization studies. The thrombin immobilized calcium alginate beads were used for the recalcification time test. The recalcification time is an indicator of bleeding time. The thrombin immobilized calcium alginate lowered recalcification time to 50 percent. Developed product has a potential to stop bleeding.
\end{abstract}

\section{Key Words}

Thrombin, immobilization, calcium alginate, stop bleeding.

\section{Ö z}

Kanama, insanlığın en büyük problemlerinden biridir. Trafik kazaları ve cerrahi operasyonlardaki kan kaybı, ölümlerin önemli bir sebebidir. Bu çalışmada, kanama süresini azaltabilecek bir ürün geliştirildi. Geliştirilen ürünün üretim süreci çok basittir. Ayrıca ürünün ticarileşme potansiyeli bulunmaktadır. Trombin, iyonik etkileşimler yoluyla kalsiyum aljinat boncuklara immobilize edildi. Bu yöntemde, kalsiyum aljinatın negatif yüklü karboksilat grupları, trombinin pozitif yükleriyle iyonik olarak etkileşime girdi. İmmobilizasyon verimini arttırmak için trombin immobilizasyonunun optimizasyon çalışmaları yapıldı. Optimizasyon çalışmalarının sonunda immobilizasyon verimi \%4.1 olarak bulundu. Trombin immobilize kalsiyum aljinat boncukları, rekalsifikasyon zamanı testi için kullanıldı. Rekalsifikasyon zamanı, kanama süresi için bir göstergedir. Trombin immobilize kalsiyum aljinat, rekalsifikasyon zamanını \%50'ye düşürdü. Geliştirilen ürün kanamayı durdurma potansiyeline sahiptir.

\section{Anahtar Kelimeler}

Trombin, immobilizasyon, kalsiyum aljinat, kanamanın durdurulması.

Article History: Received: Mar 04, 2017; Revised: Sep 12 2017; Accepted: Oct 15, 2017; Available Online: Dec 25, 2017.

Dol: $10.15671 /$ HJBC.2017.169

Correspondence txxo: A. Akkaya, Ege University, Faculty of Science, Biochemistry Department, Bornova-Izmir, Turkey 


\section{INTRODUCTION}

$\mathrm{B}$ lood loss is one of the most important problems for human life. When a large of amount of blood loses, people may die or suffer. Most of the soldiers and civilians who injured in the wars or accidents die because of the blood loss. It is one of the most frequent reasons of death. Cause of death of more than $60 \%$ of the people who died in surgery is blood loss. Even, a small amount of bleeding from incisions makes people uncomfortable in our daily life. The bleeding caused by severe injuries because of big events such as traffic and occupational accidents should immediately get stopped. If serious injury occurs, stopping bleeding has the first priority to save human life. For these reasons, the bleeding must be stopped quickly.

Stopping the bleeding occurs via coagulation process. There are two ways in the coagulation process. One of them is intrinsic pathway and the other one is extrinsic pathway. The effective pathway in coagulation is the intrinsic pathway. Coagulation is a cascade mechanism. In the final step of coagulation, thrombin catalyzes the conversion of fibrinogen to fibrin and a polymeric structure forms on a wound that prevents blood leaking out of the damaged tissue. As a result, the key reaction in coagulation is the conversion of fibrinogen to fibrin via thrombin activity [1].

If thrombin binds to a support, the developed material can stop bleeding. Alginate is a good biomaterial as a support because it could be combined with another material such as fabrics. Thus, composite materials which can stop bleeding could be developed. Based on the known researches, alginate is harmless to human body and it does not accumulate in the human body when administered orally, and does not have any toxic or inflammatory side effects [2,3]. Alginate is a water soluble linear polysaccharide extracted from brown seaweed and is composed of alternating blocks of $1 \rightarrow 4$-linked $\alpha$-L-guluronic and $\beta$-D-mannuronic acid residues. The gelation of alginate can be carried out under mild environment and uses non-toxic reactants. The most important property of alginates is their ability to form gels by reaction with divalent cations such as $\mathrm{Ca}^{2+}$ [4]. $\mathrm{Ca}^{2+}$ is a coagulation factor named Factor-IV.
If alginate gel is formed by using $\mathrm{Ca}^{2+}, \mathrm{Ca}^{2+}$ will diffuse into tissues and Factor-IV concentration will increase inside the cells. Thus, coagulation time will decrease.

The key enzyme of coagulation pathway is thrombin which is derived from inactive precursor called prothrombin after tissue or vessel injuries or after the contact of blood with a foreign surface like a surface of a biomaterial. Thrombin cleaves fibrinogen to fibrin which is polymerized, crosslinked and stabilized into a blood clot by Factor XIII, also activated by thrombin [5]. In addition, thrombin stimulates its own production by the activation of Factors V, VIII, and XI, and induces platelet activation which supports the blood clotting. Thrombin cleaves, almost exclusively, peptide bonds after arginine residues [6].

The purpose of this study was to develop a material which could stop bleeding. For this purpose, thrombin was immobilized to alginate via ionic interactions. Optimization studies were made for immobilization. Storage stability tests were also performed at different temperatures. Thrombin immobilized alginate beads were used for the recalcification time test. It has been shown that the product decreased recalcification time.

\section{MATERIALS and METHODS}

\section{Materials}

Thrombin, trizma ${ }^{\circledR}$ base, 4-nitroaniline, $\mathrm{N}-(\mathrm{p}$ tosyl)-Gly-Pro-Arg p-nitroanilide acetate salt and calcium chloride were purchased from Sigma, potassium phosphate dibasic and sodium chloride were purchased from Merck, sodium acetate and sodium alginate were purchased from Fluka. Other chemicals were commercially available and of reagent grade.

\section{Preparation of Calcium Alginate Beads}

$2 \%(\mathrm{w} / \mathrm{v})$ of sodium-alginate solution was prepared in distilled water at room temperature. The solution was kept at $4^{\circ} \mathrm{C}$ until all air bubbles disappear and then degassed under vacuum. Using a $10 \mathrm{~mL}$ syringe, the sodium-alginate solution was added drop-wise into a cold solution of $3 \%(\mathrm{w} / \mathrm{v})$ of $\mathrm{CaCl}_{2}(100 \mathrm{ml})$, with a constant stirring $(150 \mathrm{rpm})$ 
at $4^{\circ} \mathrm{C}$ for 1 hour, then, the alginate beads were washed with distilled water and stored at $4^{\circ} \mathrm{C}$.

\section{Immobilization of Thrombin to The Calcium Alginate Beads}

Calcium alginate beads were washed with phosphate buffer solution three times before usage. Alginate beads (10) and thrombin solution $(0.3 \mathrm{U})$ were added into $2 \mathrm{ml}$ phosphate buffer solution $(0.1 \mathrm{M})$ and the final solution was incubated at $+4^{\circ} \mathrm{C}$ and $250 \mathrm{rpm}$ for $1 \mathrm{~h}\left(\mathrm{~V}_{\mathrm{T}}=3 \mathrm{ml}\right)$. At the end of $2 \mathrm{~h}$, the solution was decanted and washed with buffer solution three times at $+4^{\circ} \mathrm{C}$ and $250 \mathrm{rpm}$ for $5 \mathrm{~min}$. Thrombin activities of washing solutions and alginate beads were measured according to the method given at Table 1.

Optimization studies were done for the most efficiently immobilization of thrombin to calcium alginate. For this purpose, optimization experiments were performed for the parameters given below;

pH: 3-4-5-6-7 and 8 (0.1 M of phosphate buffer). Reaction Time: 0.25-0.50-1.00-2.00 and $4.00 \mathrm{~h}$. Immobilization Temperature: 4-15-25-37 and $45^{\circ} \mathrm{C}$.

Number of Beads: 2-5-10 and 25 calcium alginate beads.

Initial Thrombin Activity: 0.075-0.150-0.3000.600 and 0.900 Unit activity.

\section{Storage Stability of The Thrombin Immobilized Calcium Alginate Beads}

Thrombin immobilized calcium alginate beads were stored at $-20^{\circ} \mathrm{C},+4^{\circ} \mathrm{C}$ and $25^{\circ} \mathrm{C}$. First, the activities of thrombin immobilized calcium alginate beads were measured and stored at different temperatures. Then, the activities of stored thrombin immobilized calcium alginate beads were measured periodically.

\section{Determination of Thrombin Activity}

Thrombin activity was determined by a spectrophotometer using a chromogenic substrate ( $\mathrm{N}$-( $\mathrm{p}$-tosyl)-Gly-Pro-Arg $\mathrm{p}$-nitroanilide acetate salt) at $405 \mathrm{~nm}$. The assay mixture was composed of $0.3 \mathrm{ml}$ of $1 \mathrm{M} \mathrm{NaCl}, 1.9 \mathrm{ml}$ of $(50 \mathrm{mM}, \mathrm{pH} 7.4)$ Tris- $\mathrm{HCl}$ buffer, $0.3 \mathrm{ml}$ of (0.2 mM) chromogenic substrate and $0.5 \mathrm{ml}$ aliquots of enzyme sample. Spectrophotometric measurement was performed at $37^{\circ} \mathrm{C}$ for $5 \mathrm{~min}$. The procedure for determination of thrombin activity was briefly given at Table 1 . The standard curve was obtained from different concentrations of p-nitroanilide to calculate thrombin activity [712]. One unit of enzyme activity was defined as the amount of enzyme catalyzing the hydrolysis of 1 $\mu \mathrm{mol}$ chromogenic substrate per minute at $37^{\circ} \mathrm{C}$ under standard assay conditions.

Table 1. Measurement procedure of thrombin activity.

\begin{tabular}{lccc}
\hline Solution & & $\begin{array}{c}\text { Blank } \\
(\mathrm{ml})\end{array}$ & $\begin{array}{c}\text { Sample } \\
(\mathrm{ml})\end{array}$ \\
\hline Tris- $\mathrm{HCl}$ & $\begin{array}{c}(50 \mathrm{mM}, \\
\mathrm{pH} \mathrm{7.4)}\end{array}$ & 2.40 & 1.90 \\
\hline $\begin{array}{l}\text { Chromogenic } \\
\text { substrate }\end{array}$ & $(0.2 \mathrm{mM})$ & 0.30 & 0.30 \\
\hline $\mathrm{NaCl}$ & $(1 \mathrm{M})$ & 0.30 & 0.30 \\
\hline Enzyme & & - & 0.50 \\
\hline
\end{tabular}

\section{Recalcification Time Test (In vitro studies)}

Recalcification time is an indicator of intrinsic coagulation cascade activation $[13,14]$. Human blood, which was collected in test tubes with ethylenediaminetetraacetic acid (EDTA), was used. For the recalcification time determination, $1 \mathrm{ml}$ of blood was carefully added to a test tube and incubated at $37 \pm 0.1^{\circ} \mathrm{C}$ for $1 \mathrm{~min} .1 \mathrm{ml}$ of calcium chloride solution (0.025 M) was added and chronometer was started. The test tube was incubated at $37 \pm 0.1^{\circ} \mathrm{C}$ for $1 \mathrm{~min}$ and coagulation was controlled by bending each test tube $80^{\circ}$ for each 10 seconds. When blood did not flow, the chronometer was stopped and time was recorded. The test was repeated with the blood of three different people for each of the thrombin immobilized calcium alginate and the blood of each person was used two times [15-17].

\section{RESULTS and DISCUSSION}

In this study, the thrombin which could reduce bleeding time was immobilized to calcium alginate on the basis of electrostatic interactions. Optimum values of immobilization reactions were determined by changing the parameters. Each optimum value was used in the next experiment. Thrombin was immobilized to calcium alginate beads at determined optimization conditions and they were used for recalcification time tests. 
For the preparation of calcium alginate beads, sodium alginate was dissolved in distilled water. During dissolution of sodium alginate, air bubbles formed in the solution. The air bubbles were supposed to be removed for two reasons: First, calcium alginate beads which include air bubbles move up to the surface of the solution. If that happens, the calcium alginate beads will not interact with thrombin. Second, air bubbles decrease the interaction area of calcium alginate beads with thrombin. Because of these reasons, bubbles were removed through degassing under vacuum. Gelation process of alginate occurs when calcium ions bound to carboxylic acid groups of glucuronic and mannuronic acid. When sodium alginate solution drops into $\mathrm{CaCl}_{2}$ solution using a syringe, solubility of alginate decreases and calcium alginate beads occur. If $\mathrm{CaCl}_{2}$ solution is cold, this will accelerate the gelling of alginate beads and the structure of the beads will be more rounded and smooth. During addition of sodium alginate solution to the $\mathrm{CaCl}_{2}$ solution, $\mathrm{CaCl}_{2}$ solution should not be stirred very quickly. If the mixing rate of the solution is very fast, the structure of the calcium alginate beads will be ellipsoid. Hardening of calcium alginate beads takes some time. Sodium and calcium ions exchange faster at the outer part of the alginate beads, but ion exchange occurs more slowly inside of the alginate beads. Therefore, the interior of the alginate beads is softer than the outer part of the alginate beads when sodium alginate solution drops to the $\mathrm{CaCl}_{2}$ solution. It takes time to reach the same hardness of the interior and other parts of the alginate beads (one hour) [18] Therefore, calcium alginate beads were incubated to equilibrate for one hour. In the assay, blunt tip needle was used to make circular calcium alginate beads.

\section{Effect of pH on Immobilization}

Proteins have amphoteric structure and net charge of them changes $\mathrm{pH}$-dependent. Their net charges are usually positive at acidic $\mathrm{pH}$ values and negative at basic $\mathrm{pH}$ values. Charge status varies according to the amino acid composition of proteins. Aspartic acid, glutamic acid and lysine are charged amino acids and these amino acids could be titrated. Carboxylate groups on aspartic and glutamic acid have negative charge at basic
$\mathrm{pH}$. When carboxylate groups titrate with acids, carboxylate groups will change to carboxylic acid and the negative charge will be lost. When the number of negative charges decreases in protein, the number of positive charges will increase in protein relatively and the net charge of the protein will be positive. Because of the amino group of Iysine, the net charge of the protein will be negative at the end of titration [19]. Enzymes are proteins molecules and have the same characteristics. As a result, the charge of the enzyme could be adjusted by changing $\mathrm{pH}$ and electrostatic interaction of the enzyme with a charged support could be achieved. For this purpose, the calcium alginate beads were treated with thrombin at $\mathrm{pH} 3-8$. Since calcium alginate beads lose negative charge at $\mathrm{pH}$ values below 3 [20]. $\mathrm{pH} 3$ and higher $\mathrm{pH}$ values were chosen for electrostatic interaction studies. The isoelectric point of the thrombin ranges $\mathrm{pH}$ 6.35-7.60 [21]. Below pH 6.35, thrombin becomes positively charged. As a result, $\mathrm{pH}$ values that calcium alginate beads have negative charge and thrombin has positive charge were chosen in the study. The best results have been obtained at $\mathrm{pH} \mathrm{3-6}$ for thrombin immobilization. Activity of thrombin immobilized calcium alginate beads was measured for different immobilization $\mathrm{pH}$ values and the results were given in Figure 1.

pH 5 was determined as the optimum value for thrombin immobilization. Thrombin precipitated at $\mathrm{pH}$ values below 5 and was soluble state in the solution. So, electrostatic interactions between calcium alginate and thrombin reduced. The activity of thrombin immobilized calcium alginate beads at $\mathrm{pH} 3$ and 4 were less than $\mathrm{pH} 5$ sample. The positive charge value of thrombin at $\mathrm{pH} 6$ was less than at pH 5 sample. Therefore, the activity of thrombin immobilized calcium alginate beads incubated at $\mathrm{pH} 6$ was lower than $\mathrm{pH} 5$ sample. The situations at $\mathrm{pH} 7$ and 8 were the same with pH 6 sample. In addition, solubility of thrombin decreased, because the isoelectric point of thrombin is $\mathrm{pH} 7$ and the net charge of thrombin was very close to zero. Therefore, electrostatic interaction of thrombin with calcium alginate weakened at $\mathrm{pH} 7$. 


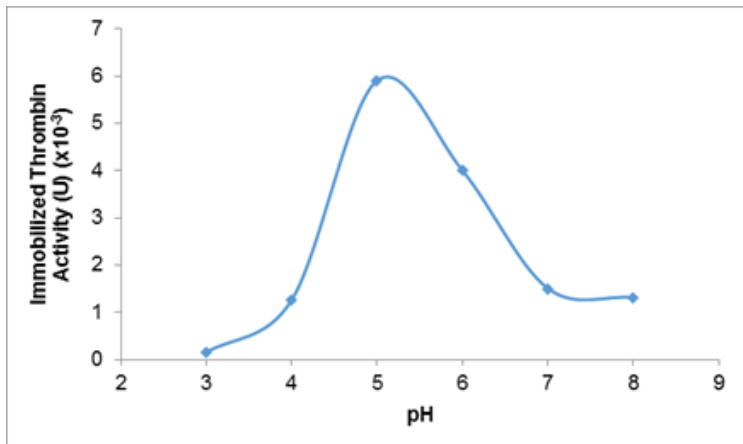

Figure 1. The effect of $\mathrm{pH}$ on thrombin immobilization to calcium alginate beads.

\section{Effect of Reaction Time on Immobilization}

After determination of the optimum $\mathrm{pH}$ value, it was necessary to determine the optimum incubation time. Because all of the charged groups in calcium alginate and thrombin required to interact with each other. This equilibration needs time and the time was the incubation time in the assays. However, enzymes are bioactive compounds and they have catalytic activities. The enzymatic activity decreases in course of time because of denaturation. Therefore, enzymes could not work continuously. At the same time, immobilization reaction time should be optimal for the prevention of losing time during the immobilization [22]. The immobilization process should be done as quickly and efficiently as possible. In this assay, immobilization process of thrombin to calcium alginate beads was performed for different incubation times. The results were given in Figure 2. As a result of the experiment, the optimum time was found as 2 hours.

The activity of thrombin immobilized calcium alginate beads increased up to 2 hours due to increased interaction time. However, the activity

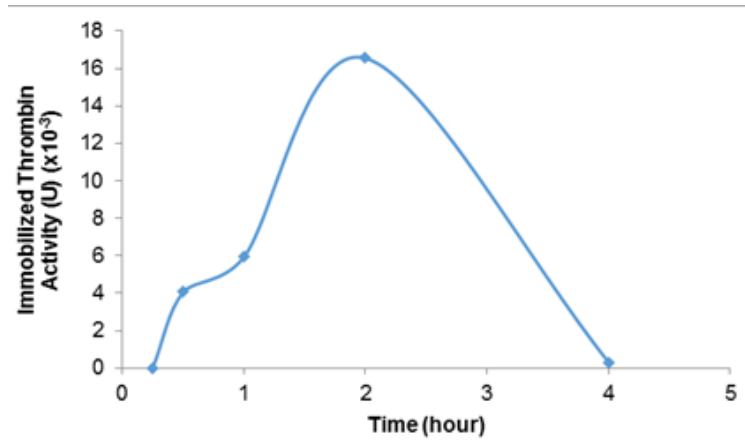

Figure 2. Effect of reaction time on thrombin immobilization to calcium alginate beads. of calcium alginate beads decreased after 2 hours because thrombin denatured. Denaturation of enzymes is a chemical process and occurs in time.

\section{Effect of Temperature on Immobilization}

The rate of a chemical reaction increases with increasing temperature. Denaturation of the enzyme is also a chemical process and the rate of denaturation increases with increasing temperature. Thus, enzymes lose their activity [23]. However, the thermostability of some enzymes is high and loss of activity with increasing temperature is not a very serious problem. This situation usually provides enhanced speed of immobilization. Thrombin immobilization was realized at 5 different temperatures between $4-45^{\circ} \mathrm{C} .4^{\circ} \mathrm{C}$ was determined to be the optimum value (Figure 3 ). At temperatures above $4^{\circ} \mathrm{C}$, the activity of thrombin immobilized calcium alginate beads decreased dramatically.

\section{Effect of the Number of Beads on Immobilization} The number of calcium alginate beads is important for ionic interactions. Because the interaction surface area of calcium alginate beads increases with increasing number of calcium alginate beads. As a result, the amount of immobilized thrombin also increases. Different number of Calcium alginate beads were used in this experiment. Thrombin activity per calcium alginate bead was used to determine the efficiency of immobilization. The results were given in Figure 4. 5 Calcium alginate beads were found to be the optimal number in the assay. 2 Beads were insufficient to bind the enzyme in solution. In 10 and 25 beads, thrombin activity per calcium alginate bead was lower than 5 calcium alginate beads.

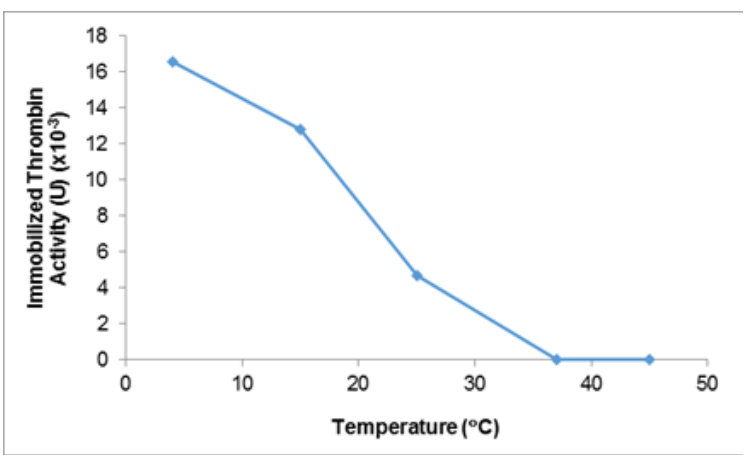

Figure 3. Effect of reaction temperature on thrombin immobilization. 


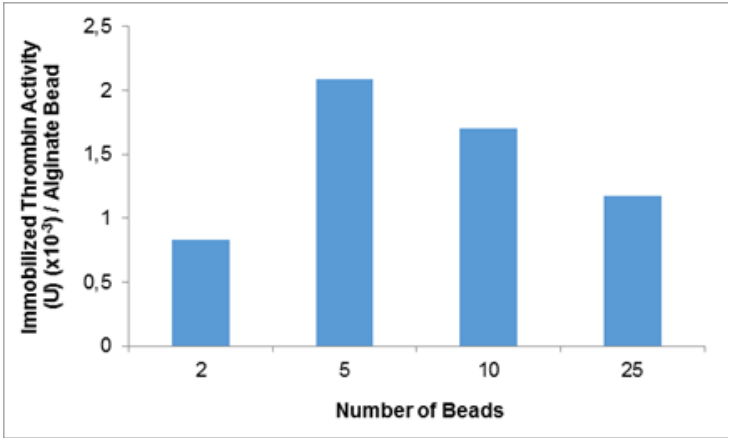

Figure 4. Effect of calcium alginate beads number on thrombin immobilization yield.

\section{Effect of Initial Enzyme Activity on Immobilization}

Protein content of enzyme preparate was very low in the study. The concentration of protein could not be measured. Therefore, binding efficiencies were determined through the activity of thrombin. Immobilization was performed at various initial thrombin activities. Results were presented in Figure 5.

Since the initial enzyme activity depends on the amount of thrombin, the low activity was obtained at the low initial amount of thrombin. As shown in the Figure 5, the amount of immobilized thrombin increased with the increased initial thrombin activity. At $0.6 \mathrm{U}$ value, immobilized thrombin activity reached a saturation point. Thus, the optimum initial thrombin activity was determined as $0.6 \mathrm{U}$. Thrombin could not immobilized values higher than $0.6 \mathrm{U}$ of thrombin because all free carboxylate groups at calcium alginate beads interacted ionically and there were no more free carboxylate groups on calcium alginate beads for thrombin immobilization.

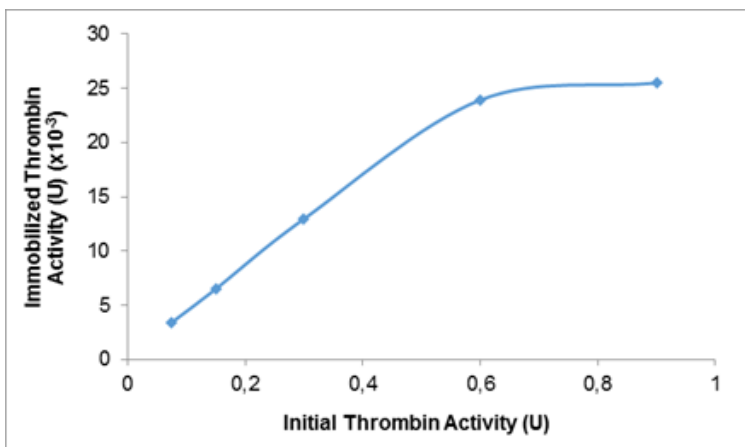

Figure 5. Effect of initial thrombin activity on thrombin immobilization.

\section{Storage Stability of the Thrombin Immobilized Calcium Alginate}

Enzymes are fragile biomolecules and lose their activity depending on the temperature. Thrombin immobilized calcium alginate beads will gradually lose its activity during storage. The storage temperature should be determined because this study focused on product development. For this purpose, thrombin immobilized calcium alginate beads were stored at $-20,4$ and $25^{\circ} \mathrm{C}$. The results were given in Figure $6 a, 6 b$ and $6 c$.

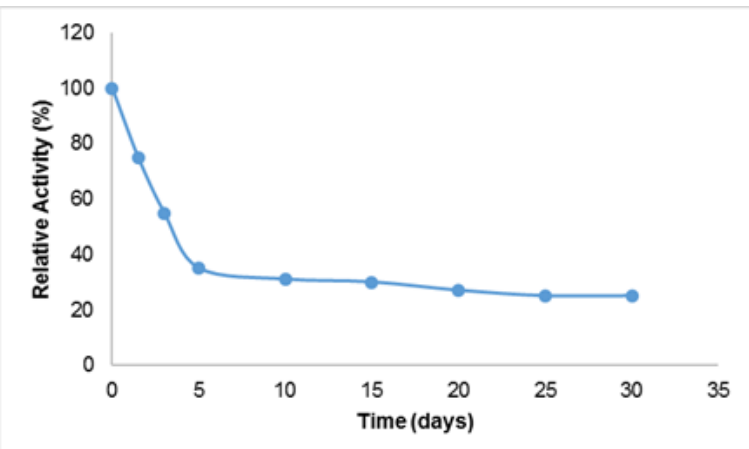

Figure 6a. Storage stability of thrombin immobilized calcium alginate at $-20^{\circ} \mathrm{C}$.

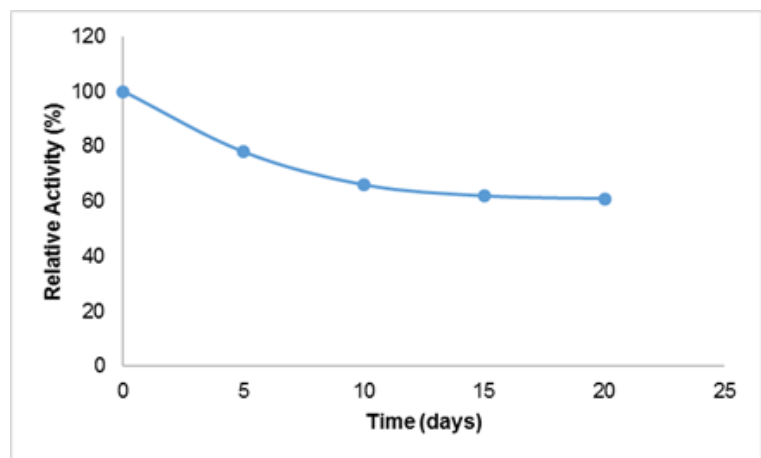

Figure 6b. Storage stability of thrombin immobilized calcium alginate at $4^{\circ} \mathrm{C}$.

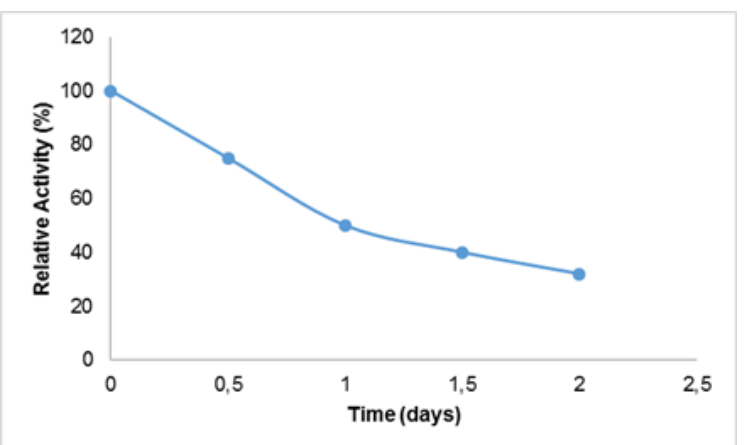

Figure 6c. Storage stability of thrombin immobilized calcium alginate at $25^{\circ} \mathrm{C}$. 
As shown in the figures, thrombin immobilized calcium alginate beads lost $70 \%$ of its enzymatic activity in two days at $25^{\circ} \mathrm{C}$. This time was very quick for developed product and $70 \%$ loss of thrombin activity was also a big value. At $-20^{\circ} \mathrm{C}$ thrombin immobilized calcium alginate beads lost $75 \%$ of its activity in 30 days. However, it lost $60 \%$ of its activity in 5 days. When the results of 4 and $-20^{\circ} \mathrm{C}$ samples were compared, thrombin immobilized calcium alginate beads lost $40 \%$ of its activity in 20 days at $4^{\circ} \mathrm{C}$ and this result was better than value of $-20^{\circ} \mathrm{C}$. Therefore, $4^{\circ} \mathrm{C}$ was chosen as the storage temperature.

\section{Effect of the Thrombin Immobilized Calcium Alginate on Recalcification Time}

Calcium ion is a cofactor of the enzymes in the coagulation cascade and very effective factor in coagulation. If there is not calcium ion, clotting does not occur. Recalcification time is an indicator of the clotting time [24]. Clotting time is usually shorter than recalcification time. In recalcification time test, first, calcium ions in the blood is removed by EDTA which has been in the test tube. Second, calcium ions are added to the same blood sample. Then, coagulation is observed. The time elapsed between clotting and calcium ion addition is defined as recalcification time. The effect of the thrombin immobilized calcium alginate beads on recalcification time was investigated under in vitro conditions. Thrombin was immobilized to calcium alginate beads at optimum conditions these beads were used in the test. Human blood was taken into test tubes that contained EDTA. According to the results, recalcification time reduced to $50 \%$ using thrombin immobilized calcium alginate beads. Since recalcification time is an indicator of the bleeding time, it is expected that bleeding time will decrease according to the recalcification time. It has predicted that using of this developed product will decrease the bleeding time more than $50 \%$. Thrombin immobilized calcium alginate may be added to medical products in the market. Thus, a composite material which can reduce the bleeding time as a new feature could be designed.

\section{CONCLUSION}

Thrombin, the key enzyme of clotting, was immobilized to calcium alginate by ionic interaction and immobilization efficiency was found as $4.1 \%$. A new product that can shorten the bleeding time was tried to develop. Thrombin bound to carboxylate groups of $\beta$-D-mannuronate residues of alginate beads. L-guluronate residues of alginate beads complexed with $\mathrm{Ca}^{+2}$ ions. Thrombin bond to alginate by electrostatic interactions and removes from the calcium alginate at high ionic strength. Ionic strength of blood is not high. Therefore, when product combine with blood, thrombin does not remove from the calcium alginate and realize the catalytic activity on calcium alginate. It has been shown that thrombin immobilized calcium alginate beads could reduce bleeding time according to the recalcification time test as an indication of bleeding time. Thrombin immobilized calcium alginate could be used directly or designed as a composite material. Thus, the medical materials can have ability to reduce the bleeding time.

The immobilization process of thrombin to calcium alginate beads was very simple and cost of the process was low. It can be a commercial product as an alternative to other products that reduce the bleeding time. Stopping bleeding product are usually extract of plants. There are a lot of metabolites in them. Extracts are penetrated to a material. This material are usually fabrics. When this product operates to bleeding wound, metabolites may combine with blood in vessels. Then, allergic reaction forms. The second problem, plant extracts stop bleeding uncontrolled. Coagulation may continue in vessels. This may cause to emboli. However, developed product in this study stop bleeding under controlled conditions. The activity of thrombin in calcium alginate is known. There are only two biomaterial in the product. First one is thrombin. Thrombin is a coagulation factor in blood. It is not a xenobiotic and allergic reactions do not occur. The second one is alginate. Alginate is used in medical sector for several purposes. It is also used as drug. It is not an allergic material. Contents of developed product is fully known. Other products are thrombin and polymer mixture, gelling polymers, thrombin solutions and powders. Advantage of developed product to other product is that developed product can be combined with materials such as fabrics. Pressure can be applied to bleeding part of human 
body using fabric as a support. Thus, bleeding can be reduced physically. Other advantage is that developed product contains calcium ions. Calcium ions are another factor of coagulation. When bleeding blood combine with developed product, some of calcium ions pass to bleeding blood and coagulation accelerates. The last advantage is that alginate is a hydrogel polymer. It sucks water of blood and concentration of coagulation factors increase. The reaction possibilities of coagulation also increase. Developed product in the study has all these advantages and other products do not have all in one. Combination of the advantages of developed product makes it more effective than existing ones. It is also a high value-added product.

\section{References}

1. K.H. Koo, M.A. Mont, L.C. Jones, Osteonecrosis, (L.C. Jones and D. McK. Ciombor, Osteonecrosis and Intravascular Coagulation Revisited). Berlin: Heidelberg Springer, 2014

2. P. Wang, Y. Song, M.D. Weir, J. Suna, L. Zhao, C.G. Simond, H.H.K. Xu, A self-setting iPSMSC-alginatecalcium phosphate paste for bone tissue engineering, Dent. Mater., 32 (2016) 252-263.

3. A. Ilie, C. Ghiulic, E. Andronescu, A. Cucuruz, A. Ficai, New composite materials based on alginate and hydroxyapatite as potential carriers for ascorbic acid, Int. J. Pharm., 510 (2016) 501-507.

4. A Akkaya, A.H. Uslan, Sequential immobilization of urease to glycidyl methacrylate grafted sodium alginate, J. Mol. Catal. B-Enzym., 67 (2010) 195-201.

5. D. Kim, T.S. Lee, The detection of thrombin using a mixture of a fluorescent conjugated polyelectrolyte and fibrinogen and implementation of a logic gate, Chem. Commun., 50 (2014) 5833-5836.

6. A. Akkaya, N.K. Pazarlioglu, Thrombin immobilization to poly(methacrylicacid) graft polymerized PET and PAN fabrics, Fiber. Polym., 14 (2013) 358-364.

7. A. Akkaya, N.K. Pazarlioglu, Thrombin immobilization to enzymatic modified PET and PAN fabrics and their applications, Fiber. Polym., 13 (2012) 985-993.

8. R. Thakur, A. Kumar, B. Bose, D. Panda, D. Saikia, P. Chattopadhyay, A.K. Mukherjee, A new peptide (Ruviprase) purified from the venom of Daboia russelii russelii shows potent anticoagulant activity via non-enzymatic inhibition of thrombin and factor Xa, Biochimie, 105 (2014) 149-158.

9. A.V. Sokolov, L. Acquasaliente, V.A. Kostevich, R. Frasson, E.T. Zakharova, G. Pontarollo, V. De Filippis, Thrombin inhibits the anti-myeloperoxidase and ferroxidase functions of ceruloplasmin: relevance in rheumatoid arthritis, Free Radical Bio. Med., 86 (2015) 279-294.
10. T. Xu, A. Lew-Tabor, M. Rodriguez-Valle, Effective inhibition of thrombin by Rhipicephalus microplus serpin-15 (RmS-15) obtained in the yeast Pichia pastoris, Ticks Tick Borne Dis., 7 (2016) 180-187.

11. D.E. Vivas-Ruiz, G.A. Sandoval, J. Mendoza, R.R. Inga, S. Gontijo, M. Richardson, E.F. Sanchez, Coagulant thrombin-like enzyme (barnettobin) from Bothrops barnetti venom: molecular sequence analysis of its cDNA and biochemical properties, Biochimie, 95 (2013) 1476-1486.

12. M.T. Cargnelutti, A.F. Marques, D. Esser, R.Q. Monteiro, M.U. Kassack, L.M.T. Lima, Allosteric activation of human $\alpha$-thrombin through exosite 2 by suramin analogs, Arch. Biochem. Biophys., 520 (2012) 36-41.

13. A. Akkaya, N.K. Pazarlioglu, Thrombin immobilization to methacrylic acid grafted poly(3-hydroxybutyrate) and its in vitro application, Prep. Biochem. Biotech., 43 (2013) 48-59.

14. M.F. Elahi, G. Guan, L. Wang, Hemocompatibility of surface modified silk fibroin materials: A Review, Rev. Adv. Mater. Sci., 38 (2014) 148-159.

15. A.H.P. Gracher, A.G. Santana, T.R. Cipriani, M. lacomini, A procoagulant chemically sulfated mannan, Carbohyd. Polym., 136 (2016) 177-186.

16. X. Xu, W. Liu, W. Li, S. Liu, Anticoagulant activity of crude extract of Holotrichia diomphalia larvae, J. Ethnopharmacol., 177 (2016) 28-34.

17. X. Wanga, L. Hu, C. Li, L. Gan, M. He, X. Hea, W. Tian, M. Li, L. Xu, Y. Li, Y. Chen, Improvement in physical and biological properties of chitosan/soyprotein films by surface grafted heparin, Int. J. Biol. Macromol., 83 (2016) 19-29.

18. J. Li, S.Y. Kim, X. Chen, H.J. Park, Calcium-alginate beads loaded with gallic acid: Preparation and characterization, LWT-Food Sci. Technol., 68 (2016) 667-673.

19. Y. Takata, R. Shimohigoshi, K. Yamamoto, J-I. Kadokawa, Enzymatic synthesis of dendritic amphoteric $\alpha$-glucans by thermostable phosphorylase catalysis, Macromol. Biosci., 14 (2014) 1437-1443.

20. A. Imeson, Food Stabilisers, Thickeners and Gelling Agents, UK. FMC BioPolymer, 2010.

21. de la Escosura-Muñiz, W. Chunglok, W. Surareungchai, A. Merkoçi, Nanochannels for diagnostic of thrombin-related diseases in human blood, Biosens. Bioelectron., 40 (2013) 24-31.

22. M. Babaei, A. Karimi, M.A. Hejazi, Use of mesoporous $\mathrm{MnO} 2$ as a support for immobilization of lipase from Candida rugose, Chem. Ind. Chem. Eng., 20 (2014) 371-378.

23. M. Elias, G. Wieczorek, S. Rosenne, D.S. Tawfik, The universality of enzymatic rate-temperature dependency, Trends Biochem. Sci., 39 (2014) 1-7.

24. A. Gao, F. Liu, L. Xue, Preparation and evaluation of heparin-immobilized poly(lacticacid) (PLA) membrane for hemodialysis, J. Membrane Sci., 452 (2014) 390-399. 